\section{Review on climate change and its effect on wildlife and}

\section{ecosystem}

\author{
Quratulann Sattar, Muhammad Ehsan Maqbool, Rabia Ehsan \\ and Sana Akhtar*
}

Department of Zoology, Wildlife and Fisheries, University of Agriculture, Faisalabad, Pakistan
Received: 22 July, 2021

Accepted: 09 August, 2021

Published: 11 August, 2021

*Corresponding author: Sana Akhtar, Department of Zoology, Wildlife and Fisheries, University of Agriculture, Faisalabad, Pakistan,

E-mail: sanaakhtar774@gmail.com

Keywords: Wildlife; Human activities; Pathogens; Greenhouse effect; Phenology

https://www.peertechzpublications.com

\section{Check for updates}

\title{
Abstract
}

This scientific literature contains numerous descriptions of climatic changes and their effect on wildlife and the ecosystem. Biodiversity and climate are interconnected to each other. The previous studies show that changes that occur in climate affect wildlife directly and indirectly. The basic cause of climatic change is human activities. Human activities increase the greenhouse gases which cause the greenhouse effect. The rising temperature of the atmosphere causes thermal optima to shift towards high altitudes and high latitudes. Global precipitation increases in the last few years that also affect the wildlife. Climate changes disturb the dynamic condition by biomass production, trophic interaction, and hydrological balance. Change climate regimes directly affect the wildlife their behavior, reproduction, migration, and foraging. Drivers of phenology such as mating, breeding, hibernation, and post-hibernation activities will benefit some species and disadvantage others this will cause a new ecosystem. Some climate parameters such as photoperiod (Drive life history events) remain the same while the timing of spring weather changed because of greenhouse gases. Some pathogens can also increase their effectiveness with changes in the climate. Climate change danger the native terrestrial wildife to extension and alters the functions and structure of their ecosystem. Therefore, it's critical to address climate change for biodiversity conservation and ecosystem management.

\section{Introduction}

Long-term variations in the abiotic factors such as temperature, rainfall, snow, and wind pattern are referred to as climatic changes (IPCC 2007a). Climate changes create new challenges for humans and wildlife, most common are cloudbursts, dry spells, increasing sea level, thawing permafrost, salinization, increased wildfires, reduced agricultural yields, water diminish, health problems due to high temperature in cities, and ablation (WWF). Climate change affects individual species and their habitat which alter the structure and function of the ecosystem and services that the natural system provided to society (Diazz, et al. 2019) Most often the climate change is limited but sometimes it spreads commonly and causes the disturbance in food chains, nutrient flow, and atmospheric circulation in other regions. Solar energy plays important role in all biological activities. It sustains most of the biomass and supports primary production. It keeps the earth's biological tolerable level. In discussing the effect of climate changes on wildlife it is noted that some species have not been much affected by these changes, while some others go to distinct. In tropical regions, there is great biodiversity because of two main phenomena: phylogenetic niche conservatism and ecological productivity. These two factors play significant roles but accumulating theoretical and experimental studies recommend that the single most important factor is kinetics: the temperature dependency of ecological and evolutionary rates. The relatively high temperatures in the tropics generate and sustain high diversity because 'the Red Queen runs faster when she is hot' [1].

Climate change has affected wildlife and the natural environment ecosystem in multiple ways. The dramatic shift in physical atmospheric conditions, climate events, and natural disasters (IPCC 2007a). Spreading wildlife diseases and invasion of exotic species are a few results of climate change that have already been observed.

In response to climate change, few species moved towards high altitudes or latitudes, but other species failed to reestablish their habitats and phenological responses. These phenomena differ among different species in the same ecosystem and ultimately causing the disintegration of ecosystem components. So, climate change should be considered as a key factor for biodiversity loss and ecosystem degradation. 
To sustain the earth's temperature in a tolerable range, the natural greenhouse effect is important. Otherwise, without it, earth temperature may decrease to $-18 \mathrm{C}$ [2].

Several human activities increase the greenhouse gases that enhance the greenhouse effect which causes global warming. This condition increases the atmospheric and sea surface temperature to cause dangerous climate change. (mcc, 1992). Sea surface temperature is increased by $0.78^{\circ} \mathrm{C}$ $\pm 0.18^{\circ} \mathrm{C}$ which intensified within the last couple of decades. (IPCC, 2007a). The average sea surface level temperature will continue to increase further $1.1^{\circ} \mathrm{C}$ to $6.4^{\circ} \mathrm{C}$ by the turn of the twenty-first century according to Climate model projections of the intergovernmental panel +of climate change. During the last 20 years rise in temperature is 8 times more than that of the last 100 years and the rate of climate change is very rapid for most species to adapt. The ability of wildlife to adapt to climate change depends critically on the rate of change [3].

\section{Sea level rise}

With increasing, sea-level temperature during the past 100 years sea level has risen by $10-25 \mathrm{~cm}$ and this level will rise further. Sea surface is in equilibrium until atmospheric temperature will increases, leading to thermal expansion of seawater. Besides, the warming atmosphere also melts the glaciers, adding more water to the ocean. (IPCC,2001).

The consequence of rising in sea level have a devastating effect on coastal habitats, it causes erosion, wetland flooding, loss of agriculture soil, contamination with salt, loss of habitat for fish, bird, and plants. An increase in sea level drives high watermark landward, due to which so many habitats are prohibited from moving inland owing to manmade or natural barriers. This results in loss of habitat like marshes and mudflats that are life-threatening to wildlife and wader species (Galbraith, et al.).

The increased sea level is the causative agent for the declining population sizes and decreased variety of shoreline intertidal invertebrates [4]. Changes in sea level can prevent the survival of coastline species in Florida key islands [5] the Key deer is an example whose habitat will be destroyed due to the rise in sea level. Inland movement of marine-derived nutrients occurs by the tidal inflow and coastline wetland that supports the land-dwelling biota. Sea level increase is not only the nutrient invasion process but also puts physical pressure on coastline populations capping in lowered yield and diversity in coastline biota [6]

The available space for coastal communities diminishes by increasing sea level which causes coastal erosion. The reduction of coastal vegetation happens due to an insufficient influx of minerals to landward. Coastal vegetation (climax communities) reverses back to main colonizers due to frequent immersion. Thus, the succession of plant communities will be repeated, and the recovery of each cycle will be slower than the first [7].

Global mean sea level budget. The net change in sea level was observed by satellite altimetry (blue curve) and the thermostatic

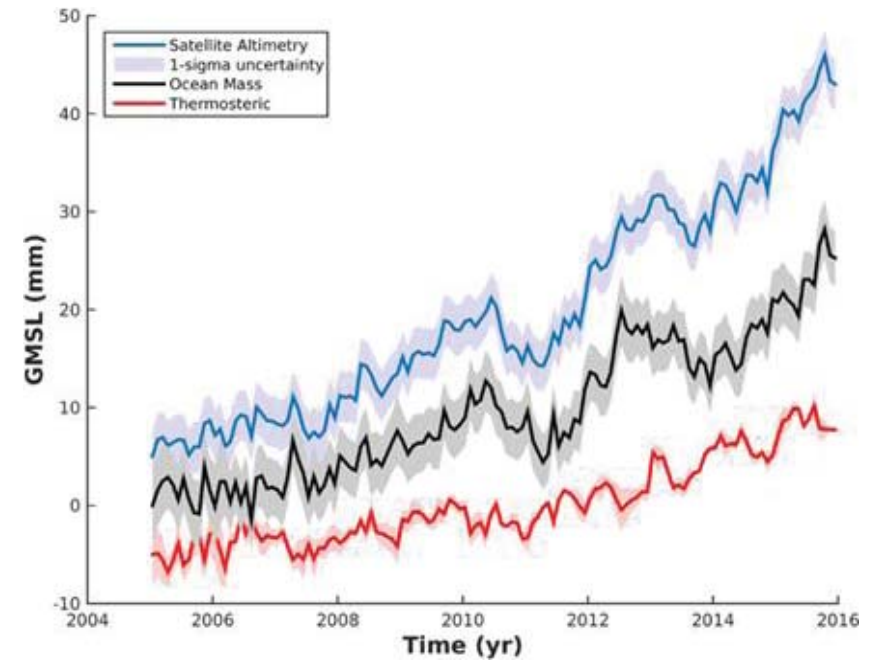

steric sea level estimated from in situ measurements (red). The indirect ocean mass inferred by removing the steric component to the observed sea level time series is shown in black. Seasonal signals have been removed from all curves. Shading denotes $1-\sigma$ uncertainty of the respective estimates. Curves are offset for clarity [8].

\section{Greenhouse effect: Intense}

The increase in carbon dioxide levels is the main cause of the greenhouse effect. George woodland determined that the level of $\mathrm{CO} 2$ is increasing with the rate of 1-2 percent per annual that can be doubled in next century. (Woods Hole Research Center). Climate changes affect wildlife directly and indirectly, but the direct effect is easier to predict as compared to indirect effects, because indirect effects occur for a long time in any region. The greenhouse effect causes an increase in temperature refers as global warming that directly affects the animal's food sources and their environment (Price and Glick, 2002). The warming climate of the earth is liable for changing phenology, thawing permafrost, sea-level rise, and glacier's shrinking (Bolen and Robinson, 2003). Scientists noticed that as the greenhouse gases are increasing the temperature of the earth also increasing gases $[9,10]$. This increasing temperature not only causes a change in rainfall or precipitation also locates animals to move towards those places that are more suitable for them [11]. Global warming changes the water's route between oceans atmosphere and land-living, it causes the change in patterns of rainfall and temperature of the local environment that affects all the features of the natural system of earth and the organisms that depend on it $[12,13]$.

There is a complex interaction between global warming and its effects on wildlife. It affects wildlife in different ways. Specific differences of species of heat tolerance, food accessibility changes, vulnerability to diseases, and changes in competitive advantages and species will modify their gathering [14].

We can see the destruction of the habitat of polar bears due to the melting of ice. Moose in North America becomes instinctive due to a decrease in ice particles (Moosely et.al.). 
Global warming changes the water's route between oceans atmosphere and land-living, it causes the change in patterns of rainfall and temperature of the local environment that affects all the features of the natural system of earth and the organisms that depend on it $[12,13]$.

Active species are less affected by global warming than active species because active species spurt fast than inactive species in case of any change in environmental temperature [15]. Species try to move towards higher altitude or poleward when temperature increase because they cannot tolerate high temperature [16] Figure 1.

(IPCC 2014) Exit based on global emissions from 2010. Details about the sources included in these estimates can be found in the Contribution of Working Group III to the Fifth Assessment Report of the Intergovernmental Panel on Climate Change

\section{Phenological shift}

In response to variation in temperature, precipitation and photoperiod changes in phenology or seasonal timing of life events have been observed in Africa [17]. The timing of spawning, reproduction and migration in animals have shifted due to phenological events in plants include leaf growth, flowering, and blooming [18-20]. Climate change can also affect wildlife in more complex ways. For example, the breeding is year-round in the African elephant (Loxodonta africana), but subordination males breed in the dry season and dominant males in the wet season. So small changes in precipitation density and drought season can change the breeding rate, ultimately genetic structure also changed in these populations [21]. As the main agriculture in the world is food production, prolonged growing seasons would also increase the cost of crops production. Multiple components of climate change differently affect the probability of species that will be driven to deterioration or extinction. It has been suggested that species that are already vulnerable are at risk of population reduction (Thomas, et al. 2004) because it takes time to adjust according to climate change (Menendez, et al. 2006). While the effect of climate change on species extinction remains controversial

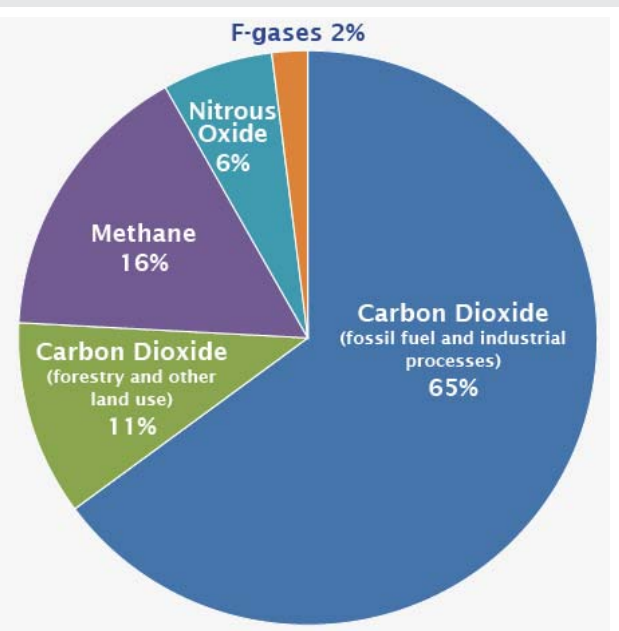

Figure 1: Global greenhouse gas emissions by gas. but it is the result that stalwartly motivates the conservation community [22]. There is greater apprehension outside the conservative community for inauspicious impacts of climate change on wildlife. The main concern is the "tripping points" that can lead to loss or irreversible shift of ecosystem, their services and functioning to human society and wind-up in a global crisis.

\section{Morphology and behavior}

Animals can subsist with environmental fluctuations by changing their morphology and behavior. Morphological alterations commonly involve changes in the size of the body [23-25]. The rise in summer temperatures, for example, has been linked to the reduced body size and increased wing length in North American migratory birds of prey [26]. Warmer temperatures can contribute to faster development rates in ectotherms [27], whose metabolic rate is sensitive to temperatures [28]. but they can also lead to smaller body sizes.

Temperatures have an unswerving effect on the human body. the direct effect of temperatures on growth has been found in [29] and Atlantic cod Throughout the northern hemisphere during recent warming the west coast of the Atlantic morphological responses on the other hand complicated. variable phenotypic alterations may go undetected if genetic change counterbalances environmental impacts [30]. Furthermore, short-term gains may not be adaptive in the long term. Behavioral reactions to climate change can be triggered by temperature changes and emerge before population and species level changes, such as distribution shifts. Changes in the population or changes in the economy [31]. Behavioral seeking shelter or refuge, adjusting feeding periods and so on some are reactions. fluctuating circadian or circannual cycles and changing site use [32].

\section{Species interactions, emergent properties and biologi- cal invasions}

The species interactions are altered by primary drivers of species exposure and responses to climate change. As species change their phonologies and distributions because of climatic changes the community characteristics like food web function and form also change that are emergent properties of an ecosystem mediated by species interaction [33]. For example, higher trophic levels are more sensitive to climate change because of changes in predatory demand, search, and encounter rate. However, functional responses vary, depending on body size [34,35], species composition, and abiotic condition [36-39] To evaluate changes in species interactions, Modeling is used but due to lack of baseline search on biotic interaction, adaptive capacity, community structure, and function, the interaction of climate and non-climate stressor but high discrepancy remains [40-42].

Many research and studies estimate that how climate alter the properties of ecosystem either directly or indirectly. [41]. The evaluation of behavioral changes, including phenological, foraging, and reproductive changes are also provided by research [40] such as ratsnake predation on birds in the

Citation: Maqbool ME, Sattar Q, Ehsan R, Akhter S (2021) Review on climate change and its effect on wildlife and ecosystem. Open J Environ Biol 6(1): 008-014. DOI: 
Southeastern United States by increasing the temperature $[43,44]$. In the end, Studies suggested that species having local adaptions $[36,45]$ or possessing population-specific traits (Della, et al. 2014; Rasmabn, et al. 2014 may survive in an unusual environment [46] Climate change enabling the introduction and spreading of invading species (Non-native species). It is assessed that the global economic cost of invasive species is currently $\$ 1.4$ trillion annually and climate change has the potential to enhance these impacts [47].

Many invasive species fluctuating community composition, dominance, production, and extinction risk of native species because they are well adapted to changing conditions $[48,49]$ For example many invasive plants to increase their competitiveness under climate change because they respond more positively to increasing $\mathrm{CO} 2$, nitrogen deposition and temperature than native plants (Liu, et al. 2017). Stouter competitive abilities will lead to an increase in the number of invasive non-native plants and cause to decline in native species [50]. In some cases, climate change reducing invasive species by indirectly assistance native species [51].

\section{Range shift}

Few studies give data about changes in distribution limits of species because of climate changes. The two main causes of range shifts in species are changes in climate and dispersal capability [52]. There is a resilient relation between velocities of distribution changes and the velocities of temperature changes [53]. Range shift is noticed in some species of insects and birds and few marine communities. The latitudinal temperate gradients are less precipitous than altitudinal temperate gradients in temperate regions (Colwell, et al. 2008). Few cases of elevational shifts seem to be driving upslope range in reptiles and amphibians [54] and amphibians and bats in Costa Rica [55]. Relocation of species does not always happen uphill $[56,57]$, particularly when changes in the environment due to climate in other direction. The rearrangement of species depends on the interaction of species and changing community dynamics, complicating general estimations (Aguirre et al). In the Amazonian lowlands in which temporal forms of rainfall are intensely different while the temperature is not, in Amazonian lowlands range shift is derived by altering precipitation. The uphill species are extinct due to climate changes because species of lower statures, have nowhere to go.

It is problematic for species to live in those environments that decline specific nasties of species with the change in conditions of the environment [58]. The population size of species is intensively affected by the change in species range due to climate change [59]. One-time wetlands were major living places of amphibians, migratory birds, and turtles, but later it changes into woodland and creates a threat to rare animals and plants [16]. The physical series of different species in the world are sifting [60]. Most habitats of species are split at higher elevations, species lose their habitat because they have no alternative habitats at these higher elevations. Habitat loss increases the extinction of these species [61]

\section{Effects on extinction}

Climate change reduced source availability like water, food supply, and breeding habitats leads to reduce reproductive abilities decrease fitness, and lower survivorship [62]. The alteration in structure, environmental favorability of habitat, and resource availability makes them unstable for native fauna and flora that leads to extinction (Omas 2004). Climate change can be a major risk factor for habitat specialist amphibians. Decreased precipitation, increased dryness, and low humidity in the south and central American cause the extinction of several amphibians for example Golden Toads (Bufo periglenes) of Costa Rica has extinct and the Harlequin frog (Atelopus varuns) suffered local extinction by two main events, increased surrounding temperature and cold born fog. Due to warming trends in tropics rainforests, many amphibians' populations are declining $[63,64]$.

Extinction of subpopulation results in loss of genetic variations through bottleneck effect, where certain genes provide phenotypic flexibility to withstand extreme climate and epidemics will be deleted from the metapopulation [65]. There have been many arguments that which biota is most susceptible to climate change. Some agreed that the most damaging effect of climate change is on high altitudes and high latitudes, primarily due to the lack of alternate habitats for migration [64]. Nonetheless, temperate, and polar species are well adapted, physiologically, morphologically, behaviorally, and biochemically against extreme climate conditions throughout their evolutionary history [66]. Species present in low latitudes are farthest from polar regions and they have to migrate long distances and cross many barriers if the climate change. This distance may serve as inevitable restrictions that stop the migration of these species in search of their suitable thermal environment [67]. Therefore, climate-imposed extinction is non-random for example the population of Edith's checkerspot butterfly (Euphydryas editha) of North America provides evidence for non-random extinction (Hughes, 2000)

Several arctic birds who nest on ice suffered population decline due to two factors imposed by global warming. First, decreasing ice sheets limits space to builds their nests, and second, the low ice cover reduced food for hatchlings [5]. Polar bear's subpopulation declined by rising spring temperature in Hudson Bay and the Canadian wildlife service linked health deterioration of polar bears during the past two decades [68].

\section{Wildlife disease and pest infestation}

All over the globe deterioration of wildlife and pest attack has been linked to climate changes. Causative agents of wildlife diseases opportunistically use climate changes in their favor. These agents may be ectoparasite, endoparasite arthropods, or disease vectors. Many factors are highlighted that can enhance the Wildlife diseases and pest densities parallel to climate change [69]. The commotion of pathogens is also increased by cold and high temperature [70], for example mosquitos development time can decrease by increasing temperature which allows greater population densities. (Gage 2008) The immunity and health condition of the host decline by hostile

Citation: Maqbool ME, Sattar Q, Ehsan R, Akhter S (2021) Review on climate change and its effect on wildlife and ecosystem. Open J Environ Biol 6(1): 008-014. DOI: 
climate change moreover pathogens and pets benefit from this condition. (Harvell 2002) Most often disease agents like fungi, viruses, and bacteria are the carrier of disease agents. Thence, an increased range of pests potentially causes pandemics [71].

In southern Alaska, British Columbia, and some parts of the northwest United States the pine bark beetle benefited from hotter and longer summer and double its turnover rate, resulting in huge tree mortality due to disastrous infection $[72,73]$. Remarkably parasites expand their distribution not only in warm climates as well as higher than normal wet conditions For example, Hawaiian honeycreepers are susceptible to Avian malaria due to the warming climate of the Islands. Avian malaria has been liable for local eradication of Hawaiian honeycreepers from swamps (lowlands). Rising temperature in the Hawaiian Islands has expanded the distribution of Anopheline mosquitos, allowing them to move into higher altitudes and attacking into previously mosquito-free areas occupied by the birds [74] Further high temperature also enhances the duration of the breeding season in some organisms that allowing contact of infected and susceptible hist so that the efficiency of pathogens to transmission has increased. For example, in some reptiles' number of copulations among mating pairs increases, allowing the parasite to spread easily [75]. Several endemic amphibian fauna are extinct in mountain areas due to the virulence of fungus achieved by two factors. Firstly, clouds cover the mountain habitat in the daytime from heating and secondly prevented loss of heat in the nighttime [51,76-86]

\section{Conclusion}

Climate change is a growing threat to wildlife, ecosystem, and ecosystem services all over the world. Climate change has the potential to inflict severe damage on the health of wildlife as well as human.

Wildlife currently faces undefeatable problems than in the past due to climate change. Impacts of climate change on biodiversity are continuous and this could result in loss of many species, habitat fragmentation, and phenological change. Even a slight temperature change will have a complex sequence in terms of species distribution and numbers. Effects of climate change are exponentially severe in highly diverse areas like the tropical rainforest. A warming climate melts the glaciers which increases sea level this affects a large number of species directly and indirectly.

Climate change may be a familiar term by now, but further attention and actions are immediately needed to be done regarding the effect of climate change. Seminars, workshops rallies, and electronic media can play an important role to create awareness in people about climate change.

\section{References}

1. Brown JH (2014) Why are there so many species in the tropics?. J Biogeogr 41: 8-22. Link: https://bit.ly/3AyVRbU

2. Abrahamson DE (1989) Global warming: the issue, impacts, responses. IN The Challenge of Global Warming. Island Press, Washington DC 3-34

3. Change C (1992) The supplementary report to the IPCC scientific assessment. Intergovernmental Panel on Cllmate Change, Cambrldge Univ Press, Cambridge. Link: https://bit.ly/3Au7GAc

4. Barry JP, Baxter CH, Sagarin RD, Gilman SE (1995) Climate-related, long-term faunal changes in a California rocky intertidal community. Science 267: 672675. Link: https://bit.ly/2VNmKK0

5. Lovejoy TD (2008) Climate change and biodiversity. Revue scientifique et technique 27: 331-338. Link: https://bit.ly/2VLIVSn

6. Titus JG (1988) Greenhouse Effect, Sea Level Rise, and Coastal Wetlands. Washington (DC): US Environmental Protection Agency. EPA 230-05-86-013. Link: https://bit.ly/3s85R91

7. Houghton JT, Ding Y, Griggs DJ, Noguer M, Van der Linden PJ, et al. (2001) Intergovernmental Panel on Climate Change (IPCC). Climate Change 2001 The Scientific Basis. Contribution of Working Group I to the Third Assessment Report of the Intergovernmental Panel on Climate Change, 881-881. Link: https://bit.ly/3xHoW38

8. Llovel W, Purkey S, Meyssignac B, Blazquez A, Kolodziejczyk N, et al. (2019) Global ocean freshening, ocean mass increase and global mean sea level rise over 2005-2015. Scientific Reports 9: 1-10. Link: https://go.nature.com/2XhIQXc

9. Nordhaus WD (2007) The challenge of global warming: economic models and environmental policy. New Haven, CT: Yale University 4. Link: https://bit.ly/3s7Blw1

10. Meinshausen M, Meinshausen N, Hare W, Raper SC, Frieler K, et al. (2009) Greenhouse-gas emission targets for limiting global warming to 2 C. Nature 458: 1158-1162. Link: https://go.nature.com/2VK6REc

11. Thornes JE (2002) IPCC, 2001: Climate change 2001: impacts, adaptation and vulnerability, Contribution of Working Group II to the Third Assessment Report of the Intergovernmental Panel on Climate Change, edited by JJ McCarthy, OF Canziani, NA Leary, DJ Dokken and KS White (eds). Cambridge University Press, Cambridge, UK, and New York, USA 1032. Link: https://bit.ly/2XcmAN3

12. Parmesan C, Yohe G (2003) A globally coherent fingerprint of climate change impacts across natural systems. Nature 421: 37-42. Link: https://go.nature.com/3yCS7Wh

13. Root TL, Price JT, Hall KR, Schneider SH, Rosenzweig C, et al. (2003) Fingerprints of global warming on wild animals and plants. Nature 421: 57-60. Link: https://bit.ly/3iDBZ1u

14. Gucinski H, Lackey RT, Spence BC (1990) Global climate change: policy implications for fisheries. Fisheries 15: 33-38. Link: https://bit.ly/3xNzwWB

15. Pearson RG, Dawson TP (2003) Predicting the impacts of climate change on the distribution of species: are bioclimate envelope models useful?. Global Ecology and Biogeography 12: 361-371. Link: https://bit.ly/2VLTx25

16. Hoegh-Guldberg $O$ (2005) Climate change and marine ecosystems. Climate change and biodiversity $256-273$.

17. Workie TG, Debella HJ (2018) Climate change and its effects on vegetation phenology across ecoregions of Ethiopia. Global Ecology and Conservation 13 e00366. Link: https://bit.ly/3yPRKaU

18. Doak DF, Morris WF (2010) Demographic compensation and tipping points in climate-induced range shifts. Nature 467: 959-962. Link: https://bit.ly/3s7CZOF

19. Miller-Rushing AJ, Høye TT, Inouye DW, Post E (2010) The effects of phenological mismatches on demography. Philosophical Transactions of the Royal Society B: Biological Sciences 365: 3177-3186. Link: https://bit.ly/3CzSRho

20. Dawson TP, Jackson ST, House JI, Prentice IC, Mace GM (2011) Beyond predictions: biodiversity conservation in a changing climate. science 332: 5358. Link: https://bit.ly/3CEZcZ5

Citation: Maqbool ME, Sattar Q, Ehsan R, Akhter S (2021) Review on climate change and its effect on wildlife and ecosystem. Open J Environ Biol 6(1): 008-014. DOI: https://dx.doi.org/10.17352/ojeb.000021 
21. Visser ME, Both C (2005) Shifts in phenology due to global climate change: the need for a yardstick. Proceedings of the Royal Society B: Biological Sciences 272: 2561-2569. Link: https://bit.ly/3yR56nH

22. Willis KJ, Bhagwat SA (2009) Biodiversity and climate change. Science 326 806-807.

23. Cheung WW, Sarmiento JL, Dunne J, Frölicher TL, Lam VW, et al. (2013) Shrinking of fishes exacerbates impacts of global ocean changes on marine ecosystems. Nature Climate Change 3: 254-258. Link: https://go.nature.com/3xzTX97

24. Eastman LM, Morelli TL, Rowe KC, Conroy CJ, Moritz C (2012) Size increase in high elevation ground squirrels over the last century. Global Change Biology 18: 1499-1508. Link: https://bit.ly/3iz84aq

25. Ozgul A, Childs DZ, Oli MK, Armitage KB, Blumstein DT, et al. (2010) Coupled dynamics of body mass and population growth in response to environmental change. Nature 466: 482-485. Link: https://go.nature.com/3iAm6IN

26. Weeks BC, Willard DE, Zimova M, Ellis AA, Witynski ML, et al. (2020) Shared morphological consequences of global warming in North American migratory birds. Ecology Letters 23: 316-325. Link: https://bit.ly/3iEekxU

27. Gardner JL, Peters A, Kearney MR, Joseph L, Heinsohn R (2011) Declining body size: a third universal response to warming?. Trends in Ecology \& Evolution 26 285-291. Link: https://bit.ly/3AyUHgM

28. Atkinson D (1994) Temperature and organism size: a biological law for ectotherms?. Advances in Ecological Research 25: 1-58. Link: https://bit.ly/2X60udl

29. Le Bris A, Pershing AJ, Gaudette J, Pugh TL, Reardon KM (2017) Multiscale quantification of the effects of temperature on size at maturity in the American lobster (Homarus americanus). Fisheries Research 186: 397-406. Link: https://bit.ly/2XmjlmB

30. Conover DO, Duffy TA, Hice LA (2009) The Covariance between Genetic and Environmental Influences across Ecological Gradients. Ann N Y Acad Sci 1168: 100-129. Link: https://bit.ly/2VK7c9W

31. Beever EA, Hall LE, Varner J, Loosen AE, Dunham JB, et al. (2017) Behaviora flexibility as a mechanism for coping with climate change. Frontiers in Ecology and the Environment 15: 299-308. Link: https://bit.ly/2XhJ67r

32. McCann EL, Johnson NS, Pangle KL (2018) Corresponding long-term shifts in stream temperature and invasive fish migration. Canadian Journal of Fisheries and Aquatic Sciences 75: 772-778. Link: https://bit.ly/37zQg92

33. Breeggemann JJ, Kaemingk MA, DeBates TJ, Paukert CP, Krause JR, et al (2016) Potential direct and indirect effects of climate change on a shallow natural lake fish assemblage. Ecology of Freshwater Fish 25: 487-499. Link: https://bit.ly/3iBUSBV

34. Peers MJ, Wehtje M, Thornton DH, Murray DL (2014) Prey switching as a means of enhancing persistence in predators at the trailing southern edge. Glob Chang Biol 20: 1126-1135. Link: https://bit.ly/3jNg2fu

35. Van Zuiden TM, Chen MM, Stefanoff S, Lopez L, Sharma S (2016) Projected impacts of climate change on three freshwater fishes and potential novel competitive interactions. Diversity and Distributions 22: 603-614. Link: https://bit.ly/3fStA8w

36. Davis CL, Miller DA, Walls SC, Barichivich WJ, Riley JW, et al. (2017) Species interactions and the effects of climate variability on a wetland amphibian metacommunity. Ecological Applications 27: 285-296. Link: https://bit.ly/2VLmLP1

37. McCluney KE, Sabo JL (2016) Animal water balance drives top-down effects in a riparian forest-Implications for terrestrial trophic cascades. Proceedings of the Royal Society B: Biological Sciences 283: 20160881. Link: https://bit.ly/3AC63AF
38. McCluney KE, Sabo JL (2016) Animal water balance drives top-down effects in a riparian forest-Implications for terrestrial trophic cascades. Proceedings of the Royal Society B: Biological Sciences 283: 20160881. Link: https://bit.ly/3xAWMa8

39. Verdeny-Vilalta O, Moya-Laraño J (2014) Seeking water while avoiding predators: moisture gradients can affect predator-prey interactions. Animal Behaviour 90: 101-108. Link: https://bit.ly/3CzTaJ4

40. Beever EA, O'Leary J, Mengelt C, West JM, Julius S, et al.. (2016) Improving conservation outcomes with a new paradigm for understanding species' fundamental and realized adaptive capacity. Conservation Letters 9: 131-137. Link: https://bit.ly/3fRQYD9

41. Blois JL, Zarnetske PL, Fitzpatrick MC, Finnegan S (2013) Climate change and the past, present, and future of biotic interactions. Science 341: 499-504. Link: https://bit.ly/3AvKWjl

42. Rosenblatt $A E$, Schmitz OJ (2014) Interactive effects of multiple climate change variables on trophic interactions: a meta-analysis. Climate Change Responses 1: 1-10. Link: https://bit.ly/3jNgcU8

43. DeGregorio BA, Westervelt JD, Weatherhead PJ, Sperry JH (2015) Indirect effect of climate change: Shifts in ratsnake behavior alter intensity and timing of avian nest predation. Ecological Modelling 312: 239-246. Link: https://bit.ly/37zpoWw

44. DeGregorio BA, Westervelt JD, Weatherhead PJ, Sperry JH (2015) Indirect effect of climate change: Shifts in ratsnake behavior alter intensity and timing of avian nest predation. Ecological Modelling 312: 239-246. Link: https://bit.ly/3seYU6f

45. Herstoff $E_{\text {, Urban } M C}$ (2014) Will pre-adaptation buffer the impacts of climate change on novel species interactions?. Ecography 37: 111-119. Link: https://bit.ly/3yD5Im9

46. Cannizzo ZJ, Griffen BD (2016) Changes in spatial behaviour patterns by mangrove tree crabs following climate-induced range shift into novel habitat. Animal Behaviour 121: 79-86. Link: https://bit.ly/2XiPoUn

47. Burgiel SW, Hall T, Adams N, Anderson K, Bella E, et al. (2014) Bioinvasions in a Changing World: A Resource on Invasive Species-climate Change Interactions for Conservation and Natural Resource Management. The Aquatic Nuisance Species Task Force (ANSTF) and The National Invasive Species Counci (NISC). Link: https://bit.ly/3kOEEII

48. Schmitt JD, Peoples BK, Castello L, Orth DJ (2019) Feeding ecology of generalist consumers: a case study of invasive blue catfish Ictalurus furcatus in Chesapeake Bay, Virginia, USA. Environmental Biology of Fishes 102: 443 465. Link: https://bit.ly/2X91EGK

49. Yeruham E, Shpigel M, Abelson A, Rilov G (2020) Ocean warming and tropical invaders erode the performance of a key herbivore. Ecology 101: e02925. Link: https://bit.ly/2VEXVQC

50. Bradley BA, Laginhas BB, Whitlock R, Allen JM, Bates AE, et al. (2019) Disentangling the abundance-impact relationship for invasive species. Proceedings of the National Academy of Sciences 116: 9919-9924. Link: https://bit.ly/3jIQsbE

51. Wenger SJ, Isaak DJ, Luce CH, Neville HM, Fausch KD, et al. (2011) Flow regime, temperature, and biotic interactions drive differential declines of trout species under climate change. Proceedings of the National Academy of Sciences 108: 14175-14180. Link: https://bit.ly/2VEY4DE

52. Williams JE, Blois JL (2018) Range shifts in response to past and future climate change: can climate velocities and species' dispersal capabilities explain variation in mammalian range shifts?. Journal of Biogeography 45 2175-2189. Link: https://bit.ly/3s9mgdx

53. Loarie SR, Duffy PB, Hamilton H, Asner GP, Field CB, et al. (2009) The velocity of climate change. Nature 462: 1052-1055. Link: https://bit.ly/3xAyHjt

Citation: Maqbool ME, Sattar Q, Ehsan R, Akhter S (2021) Review on climate change and its effect on wildlife and ecosystem. Open J Environ Biol 6(1): 008-014. DOI: https://dx.doi.org/10.17352/ojeb.000021 
54. Raxworthy CJ, Pearson RG, Rabibisoa N, Rakotondrazafy AM, Ramanamanjato $\mathrm{JB}$, et al. (2008) Extinction vulnerability of tropical montane endemism from warming and upslope displacement: a preliminary appraisal for the highest massif in Madagascar. Global Change Biology 14: 1703-1720. Link: https://bit.ly/37y66kl

55. Pounds JA, Fogden MPL, Masters KL (2005) Responses of natural communities to climate change in a highland tropical forest. 70-74 in Climate change and biodiversity, edited by T. E. Lovejoy and L. Hannah. New Haven: Yale University Press.

56. Moritz C, Patton JL, Conroy CJ, Parra JL, White GC, et al. (2008) Impact of a century of climate change on small-mammal communities in Yosemite National Park, USA. Science 322: 261-264. Link: https://bit.ly/3s7DXtM

57. Chen IC, Shiu HJ, Benedick S, Holloway JD, Chey VK, et al. (2009) Elevation increases in moth assemblages over 42 years on a tropical mountain. Proceedings of the National Academy of Sciences 106: 1479-1483. Link: https://bit.ly/3Au9rgM

58. Hinzman LD, Bettez ND, Bolton WR, Chapin FS, Dyurgerov MB, et al. (2005) Evidence and implications of recent climate change in northern Alaska and other arctic regions. Climatic change 72: 251-298. Link: https://bit.ly/3s9WHZD

59. Case M (2006) Climate change impacts on East Africa: a review of scientific literature. Link: https://bit.ly/2XcnQQh

60. Hannah L (2005) Biodiversity and climate change in context. Climate change and biodiversity. Link: https://bit.ly/3yypYjf

61. Lovejoy TE (2005) Conservation with a changing climate. Climate Change and Biodiversity. Yale University Press, New Haven 325-328.

62. Herman TB, Scott FW (1992) Threat faced by vertebrates upon global warming Climate Change 12: 88-95

63. Pounds JA, Fogden MP, Campbell JH (1999) Biological response to climate change on a tropical mountain. Nature 398: 611-615. Link: https://go.nature.com/3s9u12U

64. Parmesan C (2006) Ecological and evolutionary responses to recent climate change. Annu Rev Ecol Evol Syst 37: 637-669. Link: https://bit.ly/3Ax9sAK

65. Peters RL (1985) The greenhouse effect and nature reserves. Bioscience 35 707-717. Link: https://bit.ly/3iADIV2

66. Anisimov OA, Vaughan DG, Callaghan TV, Furgal C, Marchant H, et al. (2007) Polar Regions (Arctic and Antarctic). In: Parry, M. L., O. F. Canziani, J. P. Palutikof, P. J. van der Linden, C. E. Hanson (Eds.). Climate Change 2007: Impacts, Adaptation and Vulnerability. Contribution of Working Group II to the Fourth Assessment Report of the Intergovernmental Panel on Climate Change. Cambridge University Press. Cambridge: 653-685.

67. Lee TM, Jetz W (2008) Future battlegrounds for conservation under global change. Proc Biol Sci 275: 1261-1270. Link: https://bit.ly/2VJI2IC

68. Cosewic (2008) COSEWIC Assessment and Update on Status Report on thte Polar Bear Ursus maritimus in Canada. Committee on the Status of Endangered Wildilfe in Canada, Ottawa, Canada.

69. Harvell CD, Kim K, Burkholder JM, Colwell RR, Epstein PR, et al. (1999) Emerging marine diseases--climate links and anthropogenic factors. Science 285: 15051510. Link: https://bit.ly/3AwgOPV

70. Dukes JS, Pontius J, Orwig D, Garnas JR, Rodgers VL, et al. (2009) Responses of insect pests, pathogens, and invasive plant species to climate change in the forests of northeastern North America: What can we predict?. Canadian Journal of Forest Research 39: 231-248. Link: https://bit.ly/3yCCEFK
71. Sutherst RW (1998) Implications of global change and climate variability for vector-borne diseases: generic approaches to impact assessments. Int $J$ Parasitol 28: 935-945. Link: https://bit.ly/3ileaWl

72. Berg EE, Henry JD, Fastie CL, De Volder AD, Matsuoka SM (2006) Spruce beetle outbreaks on the Kenai Peninsula, Alaska, and Kluane National Park and Reserve, Yukon Territory: relationship to summer temperatures and regional differences in disturbance regimes. Forest Ecology and Management 227 219-232. Link: https://bit.ly/37vjfe9

73. Taylor SW, Carroll AL (2003) Disturbance, forest age, and mountain pine beetle outbreak dynamics in BC: A historical perspective. In Mountain pine beetle symposium: Challenges and solutions. Natural Resources Canada, Canadian Forest Service, Pacific Forestry Centre Victoria 3031. Link: https://bit.ly/3sbM091

74. Benning TL, LaPointe D, Atkinson CT, Vitousek PM (2002) Interactions of climate change with biological invasions and land use in the Hawaiian Islands: modeling the fate of endemic birds using a geographic information system. Proceedings of the National Academy of Sciences 99: 14246-14249. Link: https://bit.ly/3yGlHdz

75. Leuteritz TEJ, Hofmeyr MD (2007) The extended reproductive season of tent tortoises (Psammobates tentorius tentorius): a response to an arid and unpredictable environment. Journal of Arid Environments 68: 546-563. Link: https://bit.ly/3ArX1WG

76. Harvell D, Altizer S, Cattadori IM, Harrington L, Weil E (2009) Climate change and wildlife diseases: when does the host matter the most?. Ecology 90: 912920. Link: https://bit.ly/3AvhU3k

77. Alonso AA, Tabor GM (2008) Global Factors Driving Emerging Infectious Diseases: Impact on Wildlife Populations. Ann N Y Acad Sci 1149: 1-3. Link: https://bit.ly/3fQWTYW

78. Appenzeller T (1992) What Drives Climate?. Discover-New York 13: 64

79. Change IC (2014) Mitigation of climate change. Contribution of Working Group III to the Fifth Assessment Report of the Intergovernmental Panel on Climate Change, 1454. Link: https://bit.ly/3CzUsDU

80. Chen IC, Hill JK, Ohlemüller R, Roy DB, Thomas CD (2011) Rapid range shifts of species associated with high levels of climate warming. Science 333: 1024 1026. Link: https://bit.ly/3yzbD66

81. Menéndez R, Megías AG, Hill JK, Braschler B, Willis SG, et al. (2006) Species richness changes lag behind climate change. Proceedings of the Royal Society B: Biological Sciences 273: 1465-1470. Link: https://bit.ly/3fSBFda

82. Möller I, Kudella M, Rupprecht F, Spencer T, Paul M, et al. (2014) Wave attenuation over coastal salt marshes under storm surge conditions. Nature Geoscience 7: 727-731. Link: https://go.nature.com/3s7GEeV

83. Pachauri RK, Allen MR, Barros VR, Broome J, Cramer W, et al. (2014) Climate change 2014: synthesis report. Contribution of Working Groups I, II and III to the fifth assessment report of the Intergovernmental Panel on Climate Change. Ipcc 151. Link: https://bit.ly/3xCi1s5

84. Pershing AJ, Mills KE, Dayton AM, Franklin BS, Kennedy BT (2018) Evidence for adaptation from the 2016 marine heatwave in the Northwest Atlantic Ocean. Oceanography 31: 152-161. Link: https://bit.ly/3iz9a62

85. Weiskopf SR, Rubenstein MA, Crozier LG, Gaichas S, Griffis R, et al. (2020) Climate change effects on biodiversity, ecosystems, ecosystem services, and natural resource management in the United States. Science of the Total Environment 733: 137782. Link: https://bit.ly/3Ax9Nn0

86. Pounds JA, Fogden MPL, Masters KL (2005) Responses of natural communities to climate change in a highland tropical forest. Case study. See Lovejoy \& Hannah 70-74.

Copyright: (C) 2021 Sattar Q, et al. This is an open-access article distributed under the terms of the Creative Commons Attribution License, which permits unrestricted use, distribution, and reproduction in any medium, provided the original author and source are credited.

Citation: Maqbool ME, Sattar Q, Ehsan R, Akhter S (2021) Review on climate change and its effect on wildlife and ecosystem. Open J Environ Biol 6(1): 008-014. DOI: https://dx.doi.org/10.17352/ojeb.000021 